

\title{
The Determinants of UN Interventions - Are There Regional Preferences?
}

\section{PRELIMINARY VERSION - NOT FOR CIRCULATION}

\author{
Juan C. Duque* Michael Jetter ${ }^{\dagger} \quad$ Santiago Sosa ${ }^{\ddagger}$
}

April 14, 2013

\begin{abstract}
What leads the United Nations Security Council to intervene in one conflict, but remain inactive in others of similar magnitude and cruelty? This paper analyzes all registered 178 internal and internationalized internal conflicts since 1945, with the goal to unveil what determines the probability of a UN intervention. Our main focus lies on the question whether the geographical proximity to the five permanent members of the UN Security Council (China, France, Russia, the United Kingdom, and the United States) has an effect on the probability of intervention. Our results suggest that the UN is substantially more likely to intervene in conflicts located in Europe. A more detailed look at distances revels that for every 1,000 kilometers of distance from France or the United Kingdom the probability of intervention decreases by about one third. Further, we find that UN intervention is significantly more likely to happen in smaller (less population), poorer (smaller GDP per capita), and less open economies (openness to international trade).
\end{abstract}

JEL Classification: D74, F52, F53, R12

Keywords: United Nations, Conflict Resolution

\footnotetext{
${ }^{*}$ Research in Spatial Economics (RISE-group), School of Economics and Finances, EAFIT University, Medellin, Colombia; email: jduquec1@eafit.edu.co

${ }^{\dagger}$ Corresponding Author: Department of Economics, Universidad EAFIT, Medellin, Colombia; email: mjetter@eafit.edu.co; web: www.michaeljetter.com

${ }^{\ddagger}$ Universidad EAFIT, Medellin, Colombia; email: ssosanor@eafit.edu.co
} 
The United Nations is designed to make possible lasting freedom and independence for all its members. Harry S. Truman

\section{Introduction}

The United Nations name as one of their four main purposes "To keep peace throughout the world." The following pages focus particularly on the second portion of this statement - throughout the world. Many times one comes to wonder what determines whether the UN intervenes in one conflict, yet remains inactive in another conflict of similar magnitude and cruelty. This paper narrows down determinants of UN intervention by analyzing all registered 178 internal and internationalized internal conflicts between 1945 and 2011, with a specific focus on geographical aspects. Among these conflicts, the United Nations intervened in 27. Were we to look at a crude measurement for the severity of all 178 conflicts, we find that 93 are marked by at least 1,000 battle-related deaths. However, the pure correlation between conflict intensity and intervention is remarkably low (under 0.15). Thus, the pressing question remains as to how the United Nations Security Council makes his decision whether to intervene or not. Our main focus lies not only on finding general information regarding intervention determinants, but also on the question whether regional preferences could play any role here. Specifically, we look at the geographical distance to each of the five permanent members of the UN Security Council.

The general literature studying the determinants of third-party interventions has established various interesting claims. For instance, Butler (2003) concludes that “...considerations of justice may have driven U.S. decisions to employ military force in international crisis." Mullenbach and Matthews (2008) on the other hand point out the difference between domestic and international factors, which might influence a U.S. decision to intervene. ${ }^{1}$ In their findings, ideological linkage and geographical proximity come out as dominant forces. The latter argument will be of specific interest in the following pages. While geographical proximity may be an understandable determinant for intervention by a specific country (like the U.S.), any regional considerations should play no role whatsoever for a decision by the United Nations Security Council.

Specific to the United Nations, Diehl et al. (1996) examines the short- and long-term success

\footnotetext{
${ }^{1}$ Mullenbach (2005) comes to similar conclusions for third-party peacekeeping missions in general.
} 
of UN interventions, whereas Gilligan and Sergenti (2008) or Smith and Smith (2011) focus on the - sometimes unintended - consequences from UN interventions. Further, Lebovic (2004) focuses on the nations participating in an intervention and their democracy level. We want to be clear in mentioning that we are neither modelling the determinants of conflict nor the outcome of UN interventions.

The focus of our paper lies in the connection between two ideas prevalent in the respective literatures. First, Neack (1995) has hinted that states might participate in UN interventions predominantly for selfish reasons, as opposed to idealist considerations. Second, geographic proximity has been suggested as a determinant for foreign military intervention, both in general (Pearson, 1974) and in the context of the United States (Mullenbach and Matthews, 2008). We see the main contribution of this paper in finding out whether the respective conflict's geographical distance from each of the five permanent members of the UN Security Council could play any role in determining the probability of intervention. The implied selfish reasons come as fairly intuitive: with a conflict close to domestic borders, a nation might have strong interests in containing and suppressing any sources of trouble. Not only could the conflict spill over to closer countries or even to the own country, it is also substantially more likely that the domestic nation has intensive political and economic relationships with countries in their proximity. This argument follows naturally from the gravity equation in international trade and the first law of geography that "Everything is correlated with everything else, but close things are more correlated than things that are far away." (Tobler, 1970). Thus, countries could have a stronger interest to intervene in conflicts closer to home, rather than in conflict zones at the other end of the world. Yet regional considerations should not play any role in determining UN intervention, according to the UN charter.

However, our results suggest that the probability of UN intervention increases substantially if the conflict is located in Europe. More specifically, we find that for every 1,000 kilometers of distance from France or the United Kingdom the probability of intervention decreases by about 33 percent. This result remains remarkably stable in several robustness checks.

The remainder of the paper is organized as follow. Section 2 describes our sample of conflicts, whereas section 3 discusses our empirical methodology. Section 4 provides an overview of our data and section 5 presents our main results. Finally, section 6 concludes. 


\section{Conflicts}

Since the foundation of the United Nations in 1945, the Uppsala Conflict Data Program (UCDP) counts 178 conflicts (excluding extrasystemic armed conflicts between a state and a non-state group outside its own territory). ${ }^{2}$ The UN Security Council intervened in 27 of these in one or several of the following ways: $(i)$ military intervention for peacebuilding, $(i i)$ military intervention for peacekeeping, or (iii) sanctions or embargos. The UN defines a fourth method of intervention as calling for or demanding ceasing hostilities or establishment of observer mission. However, given the low commitment associated with this kind of intervention - both in financial and political terms - we decide to categorize these cases as non-intervention.

Table 1 provides a list of all 178 conflicts, indicating whether the UN did intervene - according to our above definition- or not. ${ }^{3}$ A first glance at this list tells us that the overwhelming majority of conflicts in the second part of the 20th century occurred on the African and Asian continents. Even though Asian countries were subject to more conflicts (73) than African nations (65), the UN intervened substantially more in Africa - 20 times versus 3 in Asia. Finally, the UN only intervened once on an American continent, namely in Haiti around the 1990s, when "...a military faction led by Raoul Cédras managed to oust the government of popularly elected President Jean-Bertrand Aristide." (UCDP website)

\section{Methodology}

Our variable of interest is whether the United Nations intervenes or not. Although one could specify the level of intervention further (e.g. financial or military commitments by the participating nations), it is difficult to disentangle and measure the exact level of involvement, especially considering the different time frames and circumstances under which these decisions have taken place. Thus, we model the UN decision as a binary outcome of intervention or not, in line with our categorization of intervention above.

We choose a logistic regression method as our econometric tool. Although there are only

\footnotetext{
${ }^{2}$ Including extrasystemic armed conflicts between a state and a non-state group outside its own territory did not change the general implications of our results.

${ }^{3}$ Notice that there are several double entries of the same country and year, which occurs if a country incurs various conflicts within a year.
} 
very subtle differences to a probit approach for example, we prefer the logistic model mainly because of the intuitive interpretation of the coefficients. The resulting odds ratios allow us to express the effect of a change in any independent variable on the probability of UN intervention. Specifically, our main model becomes

$$
\operatorname{logit}(p)_{i}=\alpha_{0}+\alpha_{1} \text { Intensity }_{i}+\alpha_{2} \text { Africa }+\alpha_{3} \text { Asia }+\alpha_{4} \text { Europe }+\alpha_{5} X_{i, t}+\alpha_{6} Z_{i}+\epsilon_{i, t},
$$

where $p_{i}$ is the overall probability of intervention by the United Nations Security Council in conflict $i$ (with $i \in\{0, N\}$ for $N$ overall conflicts). Intensity describes the severeness of the respective conflict, whereas continental dummies (Africa, Asia, and Europe) capture where the host country of the conflict is located. ${ }^{4}$

Further, $X_{i, t}$ contains several control variables, describing the main macroeconomic and political characteristics of the respective conflict country: (i) population size, (ii) GDP per capita, (iii) openness to trade, and (iv) the Polity IV variable measuring the degree of democratization in the conflict nation. All of these are measured at the starting year of the respective conflict, indicated by the subscript $t$. Regarding population size, one could think of two intuitions why the UN might intervene: first, a bigger society means that the potential human loss could be greater; second, the more people you have, the more potential soldiers there are. The first argument promotes a positive relationship between population size and probability of intervention, whereas the latter argument could motivate either relationship. For instance, a negative effect could be caused by the cost of intervention increasing with more soldiers being involved. ${ }^{5}$ These intuitions are also closely related to income per capita, as the opportunity cost of joining an army could naturally be lower when income is low in the first place. For a good review on the economic causes of civil war, one might consider the work of Paul Collier in general and Collier and Hoeffler (1998) specifically. Another reason for the importance of basic macroeconomic factors in this context is the fact that the UN may have a paternalistic view in trying to defend people that otherwise are not able to defend themselves. This philosophy is currently being

\footnotetext{
${ }^{4}$ There have been too few conflicts in Oceania and only one intervention on the American continents, thus making the inclusion of those continental dummies obsolete.

${ }^{5}$ For a general intuition of the relationship between conflict and the size of countries, one might consult Alesina and Spolaore (2005).
} 
underlined by the UN initiative "responsibility to protect" (R2P). This is reinforced by the fact that UN members have accepted the declaration of human rights and international humanitarian conventions. ${ }^{6}$

In addition, $Z_{i, t}$ captures the geographical aspect of our analysis. First, $Z_{i, t}$ contains basic location features, namely dummies for continents and whether the country is landlocked or an island. Further, one of the main components of our analysis is the distance of the respective conflict nation to the five permanent members of the United Nations Security Council. In theory, these geographical distances should not make any difference in the decision to intervene, yet it has often been argued (albeit mostly in newspapers and anecdotal discussions) that those decisions may carry a geographical component. We see this analysis of the geographical aspect as the main contribution of our paper - first, by the inclusion of basic continental dummies and second, more specifically, by the inclusion of the geographical proximity to China, France, Russia, the United Kingdom, and the United States. Finally, $\epsilon_{i, t}$ constitutes the usual error term.

\section{Data}

\subsection{Basic Descriptive Statistics}

Table 2 shows the summary statistics of all variables used in our analysis. Our binary dependent variable interv - whether the UN intervenes in a conflict area or not - comes directly from the UN Security Council's resolutions and is equal to one if the UN intervened according to our above categorization. The first and potentially most intuitive independent variable predicting an intervention is the intensity of the conflict (intensity). We would expect that as the intensity of the conflict increases, so does the probability of intervention. The UCDP allows us to categorize the severity of the conflict into "between 25 and 999 battle-related deaths" and conflicts with more than 1,000 battle-related deaths.

Further, we use the Penn World Table version 7.1 for main macroeconomic features of the countries, such as population size, GDP percapita, and openness to trade, each taken at the first

\footnotetext{
${ }^{6}$ For a recent contribution towards the connection between regional trade agreements and conflicts, one might consider Martin et al. (2012).
} 
year of the respective conflict (lnpop, lngdp, and lnopen). In our main specifications, we employ the natural logarithm of each of these, to achieve better comparability of results, although not using logs does not change our general conclusions.

To capture the level of democracy, we incorporate the Polity IV index (polityIV), in particular the variable polity2, ranging from -10 (totally autocratic) to +10 (total democracy). Moving to the main focus of our paper, we include continental dummies and eventually the shortest distance of the respective conflict country to each of the five permanent members of the UN: the Untied Kingdom (ukdist), France (fradist), China (chidist), Russia (rusdist), and the United States (usdist). In addition, we add dummies for a country being landlocked or being an island.

\subsection{Summary Statistics of Conflicts}

Table 3 displays a variety of characteristics, comparing conflicts where the UN intervened to conflicts where the UN did not intervene and to general worldwide averages. This descriptive table provides both a basic understanding of the differences between intervention and nonintervention cases (column 2 versus column 3), but also an idea of what distinguishes the host nation of a conflict from the rest of the world (columns 2 and 3 versus column 4). Starting with the latter comparison, a few features are standing out: conflict countries are $(i)$ substantially poorer than the world average in terms of GDP per capita and (ii) less open to international trade. The fact that the group of conflict countries is both larger in terms of population (on average 85 million people, as opposed to 22.8 million as a world average) and less open to international trade is in line with previous findings. Alesina and Wacziarg (1998) argue that larger economies are generally less open to trade, simply because they are able to rely on a bigger domestic market.

Focusing on the conflict nations, we note some remarkable difference between cases of UN intervention and non-intervention. First, intervention is very unlikely to occur in highly populated countries, as the average country size for intervention cases is 7.2 million people, compared to 101.4 million people in non-intervention cases. This difference is astonishing. Second, mean income per capita is twice the size in non-intervention countries, suggesting that the UN is more likely to intervene in the poorest nations, with an average of only US $\$ 1,850$ in 2005 constant 
prices (PPP adjusted). In addition, the UN appears to be more likely to intervene in less democratic (and more autocratic) nations, as suggested by the polity IV index. Finally, we notice some interesting regional differences: probability of UN intervention seems to rise in countries that happen to be further away from France (3,650 kilometers on average versus 5,050 kilometers in non-intervention cases) or located in Europe in general. Further, intervention seems to be more likely in Africa, but less likely in Asia or countries close to China. Finally, distance to the United States does not seem to make any difference.

Although these basic descriptive statistics give us some idea about the characteristics of conflicts and intervention cases, one needs to be careful not to read too much into them. The following regression analysis will provide more insight into what remains as determining factors of UN intervention.

\section{$5 \quad$ Empirical Results}

\subsection{The Continent of Conflict}

Tables $4-6$ show our main results from logistic regressions. In all tables, we display six regressions with the odds ratio of the respective variables and the standard errors below in parentheses. The intuition of odds ratio suggests that any values bigger than 1 increase the odds of intervention, whereas a value below 1 stands for a decrease in the probability of the UN intervening. In each table, we add regressors moving from left to right, predicting the probability of UN intervention.

We first focus on the location of the respective conflicts by introducing continental dummies in table 4. Although African conflicts seem to increase the odds of intervention at first, this impression quickly fades when adding macroeconomic country features, such as population size or GDP per capita and openness to trade. Further including the Polity IV index and regional specifics in column (5) pushes the odds ratio under 1, indicating that being in Africa actually decreases the probability of intervention. However, this result is not significant. The results for

Europe on the other hand are stronger. Throughout all six regressions, the European dummy is significant on conventional levels, with the odds ratio staying well above 1 . This indicates that European countries have a bigger probability of UN intervention than the rest of the world. 
The suggested magnitude of this effect is stunning: in our final specification with all our control variables included, intervention is 16 times more likely in European countries compared to the rest of the world.

The remaining regressors mostly confirm our initial suspicion from looking at plain summary statistics in table 3 . Higher intensity of the conflict increases the probability of intervention by a factor of 7.3 in the final specification. Further, the UN is significantly less likely to intervene in (i) bigger countries, (ii) richer countries, and (iii) countries which are more open to international trade. Surprisingly, the level of democracy in the conflict country does not seem to play any decisive role for an intervention decision; neither do general geographical features such as whether the country is landlocked or an island. Finally, the coefficient on year is above 1 and significant, indicating that the UN was more likely to intervene in recent conflicts. Every year increases the odds of intervention by 11 percent. We find it also noteworthy to mention that a dummy variable for conflicts during the Cold War (before 1991) neither affects the significance levels nor the magnitude of our results (not displayed here, but available upon request).

In summary, these results suggest that the probability of intervention strongly increase if a conflict takes place in Europe. Note that these results do not imply a negative bias against African or Asian countries, but rather a positive bias in favor of intervention in European conflicts. However, if we look at the summary of conflicts in table 1, we note that UN intervention in Europe exclusively took place throughout the wars in former Yugoslavia in the 1990s (interventions three times in Bosnia and Herzegovina, twice in Serbia, and once in Croatia). If we were to broadly consider the Yugoslavian wars as one major conflict zone, then our results with respect to European conflicts may be driven by this one big conflict only. Thus, we now move to a more sophisticated measurement of the geography of conflicts by considering the geographical proximity of the conflict nation to each of the five permanent members in the UN Security Council.

\subsection{The Conflict's Geographical Distance to the UN}

As a more detailed measurement of geographical proximity relative to the five permanent members of the UN Security Council, we now move to the inclusion of distances in kilometers. First, we consider the distance to the United Kingdom, measured in 1,000 kilometers, in table 5. Again 
adding control variables from left to right, we note that the odds ratio on ukdist remains below 1 and statistically meaningful. This suggests that a larger geographical distance to Britain significantly decreases the probability of intervention, leaving the remaining control variables unchanged. In terms of magnitude, the final specification including all available control variables concludes that every 1,000 kilometers of distance from the UK decreases the probability of intervention by about 30 percent. Regarding the other regressors, the results are mostly in line with the ones from table 4 .

Moving to another permanent member of the UN Security Council, we now consider the geographical proximity to France in table 6. We find similar results to the previous findings, as the distance to France remains significant throughout all specifications. Once again, every 1,000 kilometers of distance lowers the probability of intervention by about 30 percent. However, given the strong correlation between distances to Britain and France, these results mostly serve as a confirmation of the findings in table 5 .

We now turn to the other permanent members of the UN Security Council: China, Russia, and the United States. Table 7 replicates specifications (2) and (6) from table 6, this time including the distances from China, Russia, and the United States. However, we do not find the strong results from the previous tables, neither in terms of significance nor in magnitude: distance to either China, Russia, or the U.S. does not seem to play any role in determining the probability of UN intervention. This is specifically interesting in the context of the United States with their strong involvement in many conflict areas worldwide. One explanation could be that the U.S. tends to pursue their interventions in a more direct way, thus not always looking for the United Nations as the primary organization of intervention. These claims are highly speculative of course and should provide further avenues for future research.

\section{Conclusions}

This paper pursues two main objectives. First, we wish to shed light on what determines interventions by the United Nations Security Council in general. Second, we analyze whether the geographical proximity to any of the five permanent members of the UN Security Council play any role in determining the probability of intervention. Given the United Nations' goal "To 
keep peace throughout the world," the decision to intervene, both militarily (peacebuilding and peacekeeping) and by sanctions, should theoretically not be affected by geographical location. However, our results suggest that the larger the geographical distance to France or the United Kingdom, the lower the probability of UN intervention. Specifically, for every 1,000 kilometers of distance, the probability of intervention seems to decrease by 30 percent, everything else equal. Interestingly, we do not find any significant results for distances to the other three permanent members (China, Russia, and the United States). Thus, the traditional big European political powers appear to have a strong political influence in the UN's decisions about conflict intervention.

In addition to our geographical results, we also find that the UN is significantly more likely to intervene in $(i)$ less populated countries, (ii) the poorest nations, and (iii) countries, which are less open to international trade. We leave it up to the reader to draw any potential conclusions from these findings. 


\section{References}

Alesina, A. and Spolaore, E. (2005). War, peace, and the size of countries. Journal of Public Economics, 89(7):1333-1354.

Alesina, A. and Wacziarg, R. (1998). Openness, country size and government. Journal of Public Economics, 69(3):305-321.

Butler, M. J. (2003). Us military intervention in crisis, 1945-1994 an empirical inquiry of just war theory. Journal of Conflict Resolution, 47(2):226-248.

Collier, P. and Hoeffler, A. (1998). On economic causes of civil war. Oxford economic papers, $50(4): 563-573$.

Diehl, P., Reifschneider, J., and Hensel, P. (1996). United nations intervention and recurring conflict. International Organization, 50:683-700.

Gilligan, M. J. and Sergenti, E. J. (2008). Do un interventions cause peace? using matching to improve causal inference. Quarterly Journal of Political Science, 3(2):89-122.

Lebovic, J. (2004). Uniting for peace? democracies and united nations peace operations after the cold war. Journal of Conflict Resolution, 48(6):910-936.

Martin, P., Mayer, T., and Thoenig, M. (2012). The geography of conflicts and regional trade agreements. American Economic Journal: Macroeconomics, 4(4):1-35.

Mullenbach, M. (2005). Deciding to keep peace: An analysis of international influences on the establishment of third-party peacekeeping missions. International Studies Quarterly, 49(3):529556.

Mullenbach, M. J. and Matthews, G. P. (2008). Deciding to intervene: An analysis of international and domestic influences on united states interventions in intrastate disputes. International Interactions, 34(1):25-52.

Neack, L. (1995). Un peace-keeping: In the interest of community or self? Journal of Peace Research, 32(2):181-196. 
Pearson, F. (1974). Geographic proximity and foreign military intervention. Journal of Conflict Resolution, 18(3):432-460.

Smith, C. A. and Smith, H. M. (2011). Human trafficking: The unintended effects of united nations intervention. International Political Science Review, 32(2):125-145.

Tobler, W. R. (1970). A computer movie simulating urban growth in the detroit region. Economic geography, 46:234-240. 
Table 1: Conflicts since 1945

\begin{tabular}{|c|c|c|c|c|c|}
\hline Country & Year & UN intervention & Country & Year & UN intervention \\
\hline \multicolumn{3}{|c|}{ Africa } & \multicolumn{3}{|c|}{ Africa cont. } \\
\hline Congo, Dem. Rep. & 1960 & & Senegal & 1988 & \\
\hline Cameroon & 1960 & & Comoros & 1989 & \\
\hline Ethiopia & 1960 & & Mali & 1990 & \\
\hline Congo, Dem. Rep. & 1960 & Yes & Algeria & 1990 & \\
\hline Ethiopia & 1961 & & Rwanda & 1990 & Yes \\
\hline Sudan & 1963 & & Ethiopia & 1991 & \\
\hline Ethiopia & 1964 & & Sierra Leone & 1991 & Yes \\
\hline Congo, Dem. Rep. & 1964 & Yes & Niger & 1991 & \\
\hline Gabon & 1964 & & Djibouti & 1991 & \\
\hline Burundi & 1965 & Yes & Angola & 1991 & \\
\hline Chad & 1966 & Yes & Eritrea & 1993 & \\
\hline Nigeria & 1966 & & Congo, Rep. & 1993 & \\
\hline Ghana & 1966 & & Niger & 1994 & \\
\hline South Africa & 1966 & & Niger & 1995 & \\
\hline Zimbabwe & 1966 & Yes & Comoros & 1997 & \\
\hline Cambodia & 1967 & Yes & Lesotho & 1998 & \\
\hline Nigeria & 1967 & & Congo, Dem. Rep. & 1998 & \\
\hline Morocco & 1971 & & Guinea-Bissau & 1998 & Yes \\
\hline Uganda & 1971 & & Guinea & 2000 & \\
\hline Madagascar & 1971 & & Central African Republic & 2001 & Yes \\
\hline Sudan & 1971 & Yes & Cote d'Ivoire & 2002 & Yes \\
\hline Ethiopia & 1974 & & Nigeria & 2003 & \\
\hline Ethiopia & 1975 & & Nigeria & 2004 & \\
\hline Mauritania & 1975 & & Mauritania & 2008 & \\
\hline Angola & 1975 & Yes & Sudan & 2011 & \\
\hline Morocco & 1975 & & Sudan & 2011 & Yes \\
\hline Mozambique & 1977 & & Libya & 2011 & Yes \\
\hline Ethiopia & 1977 & & \multirow{2}{*}{\multicolumn{3}{|c|}{ Asia }} \\
\hline South Africa & 1978 & & & & \\
\hline Tunisia & 1980 & & & & \\
\hline Liberia & 1980 & Yes & Russian Federation & 1945 & \\
\hline Egypt, Arab Rep. & 1981 & & Iran, Islamic Rep. & 1945 & \\
\hline Gambia, The & 1981 & & Russian Federation & 1946 & \\
\hline Kenya & 1982 & & China & 1946 & \\
\hline Somalia & 1982 & Yes & Philippines & 1946 & \\
\hline Ethiopia & 1982 & & Iran, Islamic Rep. & 1946 & \\
\hline Togo & 1986 & & China & 1947 & \\
\hline Burkina Faso & 1987 & & Myanmar & 1948 & \\
\hline Senegal & 1988 & & Myanmar & 1948 & \\
\hline Comoros & 1989 & & Myanmar & 1948 & \\
\hline Mali & 1990 & & Israel & 1948 & \\
\hline Algeria & 1990 & & Myanmar & 1948 & \\
\hline Rwanda & 1990 & Yes & India & 1948 & \\
\hline Ethiopia & 1991 & & Myanmar & 1949 & \\
\hline Sierra Leone & 1991 & Yes & China & 1950 & \\
\hline Niger & 1991 & & Indonesia & 1950 & \\
\hline Djibouti & 1991 & & Thailand & 1951 & \\
\hline Angola & 1991 & & Indonesia & 1953 & \\
\hline Eritrea & 1993 & & India & 1955 & \\
\hline Congo, Rep. & 1993 & & Vietnam & 1955 & \\
\hline Niger & 1994 & & Malaysia & 1957 & \\
\hline Niger & 1995 & & Myanmar & 1957 & \\
\hline Comoros & 1997 & & Oman & 1957 & \\
\hline Lesotho & 1998 & & Iraq & 1958 & \\
\hline Congo, Dem. Rep. & 1998 & & Lebanon & 1958 & Yes \\
\hline Guinea-Bissau & 1998 & Yes & Lao PDR & 1959 & \\
\hline Guinea & 2000 & & Myanmar & 1959 & \\
\hline
\end{tabular}


Table 1 cont. Conflicts since 1945

\begin{tabular}{|c|c|c|c|c|c|}
\hline Country & Year & UN intervention & Country & Year & UN intervention \\
\hline \multicolumn{3}{|c|}{ Asia cont. } & \multicolumn{3}{|c|}{ Europe } \\
\hline Nepal & 1960 & Yes & Greece & 1946 & \\
\hline Iraq & 1961 & & France & 1961 & \\
\hline Malaysia & 1963 & & Spain & 1968 & \\
\hline Thailand & 1965 & & United Kingdom & 1970 & \\
\hline Indonesia & 1965 & & Romania & 1989 & \\
\hline India & 1966 & & Georgia & 1991 & \\
\hline Syrian Arab Republic & 1966 & & Azerbaijan & 1991 & \\
\hline Oman & 1968 & & Georgia & 1991 & \\
\hline Philippines & 1970 & & Serbia & 1991 & Yes \\
\hline Pakistan & 1971 & & Moldova & 1991 & \\
\hline Sri Lanka & 1971 & & Serbia & 1991 & \\
\hline Iran, Islamic Rep. & 1972 & & Croatia & 1992 & Yes \\
\hline Pakistan & 1973 & & Bosnia and Herzegovina & 1992 & Yes \\
\hline Myanmar & 1973 & & Bosnia and Herzegovina & 1992 & Yes \\
\hline Bangladesh & 1975 & & Georgia & 1992 & \\
\hline Indonesia & 1975 & & Azerbaijan & 1993 & \\
\hline Sri Lanka & 1975 & & Bosnia and Herzegovina & 1993 & Yes \\
\hline Afghanistan & 1978 & Yes & Serbia & 1996 & Yes \\
\hline India & 1979 & & Macedonia, FYR & 2000 & \\
\hline Saudi Arabia & 1979 & & \multirow{2}{*}{\multicolumn{3}{|c|}{ North America }} \\
\hline India & 1979 & & & & \\
\hline Iran, Islamic Rep. & 1979 & & & & \\
\hline India & 1981 & & Cuba & 1953 & \\
\hline India & 1983 & & Dominican Republic & 1965 & \\
\hline Turkey & 1983 & & Haiti & 1989 & Yes \\
\hline India & 1984 & & Panama & 1989 & \\
\hline Israel & 1986 & & Trinidad and Tobago & 1990 & \\
\hline Turkey & 1987 & & Mexico & 1994 & \\
\hline India & 1989 & & United States & 2001 & \\
\hline Indonesia & 1989 & & \multirow{2}{*}{\multicolumn{3}{|c|}{ Latin America }} \\
\hline Russian Federation & 1990 & & & & \\
\hline Russian Federation & 1990 & & & & \\
\hline Pakistan & 1990 & & Bolivia & 1946 & \\
\hline Tajikistan & 1992 & & Paraguay & 1947 & \\
\hline Tajikistan & 1992 & & Costa Rica & 1948 & \\
\hline Russian Federation & 1993 & & Guatemala & 1949 & \\
\hline India & 1993 & & Argentina & 1955 & \\
\hline Yemen, Rep. & 1994 & & Venezuela, RB & 1962 & \\
\hline Russian Federation & 1994 & & Colombia & 1964 & \\
\hline Myanmar & 1997 & & Peru & 1965 & \\
\hline Russian Federation & 1999 & & Uruguay & 1970 & \\
\hline Uzbekistan & 1999 & & El Salvador & 1972 & \\
\hline India & 2004 & & Chile & 1973 & \\
\hline India & 2005 & & Nicaragua & 1974 & \\
\hline Russian Federation & 2007 & & Suriname & 1986 & \\
\hline \multirow[t]{3}{*}{ Myanmar } & 2009 & & & & \\
\hline & & & \multicolumn{3}{|c|}{ Oceania } \\
\hline & & & Papua New Guinea & 1989 & \\
\hline
\end{tabular}


Table 2: Summary statistics

\begin{tabular}{|c|c|c|c|c|c|}
\hline Variable & Mean & (Std. Dev.) & $\mathbf{N}$ & Source & Description \\
\hline interv & 0.15 & $(0.36)$ & 178 & $\mathrm{UN}$ & $\begin{array}{l}\text { Dummy }=1 \text { if economic sanctions } \\
\text { or arms embargo, peacekeeping op- } \\
\text { erations, and/or military interven- } \\
\text { tion (peacebuilding) } ;=0 \text { otherwise }\end{array}$ \\
\hline intensity & 0.51 & $(0.50)$ & 178 & $\mathrm{UCDP}$ & $\begin{array}{l}0 \text { if between } 25 \text { and } 999 \text { battle- } \\
\text { related deaths; } 1 \text { if at least } 1,000 \\
\text { battle-related deaths }\end{array}$ \\
\hline $\ln$ pop & 16.57 & $(1.79)$ & 151 & PWT & $\ln ($ population $) ;$ variable $P O P$ \\
\hline $\operatorname{lngdp}$ & 7.49 & $(1.07)$ & 130 & PWT & $\begin{array}{l}\ln [\text { PPP Converted GDP } \\
\text { Capita (Laspeyres) at } 2005 \text { con- } \\
\text { stant prices]; variable } r g d p l\end{array}$ \\
\hline lnopen & 3.65 & $(0.75)$ & 130 & PWT & $\begin{array}{l}\ln (\text { Openness at } 2005 \text { constant prices } \\
\text { in \%); variable openk }\end{array}$ \\
\hline polityIV & -0.49 & $(6.45)$ & 168 & Polity IV & $\begin{array}{l}\text { level of democracy, ranging from - } \\
10 \text { (totally autocratic) to }+10 \text { (total } \\
\text { democracy); variable polity } 2\end{array}$ \\
\hline ukdist & 5.37 & $(2.70)$ & 178 & own & $\begin{array}{l}\text { distance to the United Kingdom in } \\
\text { thousand kilometers }\end{array}$ \\
\hline fradist & 4.84 & $(2.82)$ & 178 & own & $\begin{array}{l}\text { distance to France in thousand } \\
\text { kilometers }\end{array}$ \\
\hline chidist & 4.36 & $(4.03)$ & 178 & own & $\begin{array}{l}\text { distance to China in thousand } \\
\text { kilometers }\end{array}$ \\
\hline rusdist & 3.48 & $(2.87)$ & 178 & own & $\begin{array}{l}\text { distance to Russia in thousand } \\
\text { kilometers }\end{array}$ \\
\hline usdist & 8.02 & $(3.05)$ & 178 & own & $\begin{array}{l}\text { distance to the United States in } \\
\text { thousand kilometers }\end{array}$ \\
\hline africa & 0.37 & $(0.48)$ & 178 & own & Dummy $=1$ if country in Africa \\
\hline asia & 0.41 & $(0.49)$ & 178 & own & Dummy $=1$ if country in Asia \\
\hline europe & 0.11 & $(0.31)$ & 178 & own & Dummy $=1$ if country in Europe \\
\hline namerica & 0.04 & $(0.19)$ & 178 & own & $\begin{array}{l}\text { Dummy }=1 \text { if country in North } \\
\text { America }\end{array}$ \\
\hline oceania & 0.01 & $(0.07)$ & 178 & own & Dummy $=1$ if country in Oceania \\
\hline smamerica & 0.07 & $(0.26)$ & 178 & own & $\begin{array}{l}\text { Dummy }=1 \text { if country in Latin } \\
\text { America }\end{array}$ \\
\hline landlocked & 0.20 & $(0.40)$ & 178 & & Dummy $=1$ if country is landlocked \\
\hline island & 0.10 & $(0.30)$ & 178 & & Dummy $=1$ if country is an island \\
\hline
\end{tabular}

Notes: UCDP and PWT stand for Uppsala Conflict Data Program and Penn World Table Version 7.1, respectively. UN represents the UN Security Council resolutions. 
Table 3: Comparing UN intervention cases to non-intervention cases and to worldwide averages

\begin{tabular}{|c|c|c|c|}
\hline Variable & $\begin{array}{l}\text { Interventions } \\
\text { Mean } \\
\text { (Std. Dev.) } \\
\text { N }\end{array}$ & $\begin{array}{c}\text { Non-interventions } \\
\text { Mean } \\
\text { (Std. Dev.) } \\
\text { N }\end{array}$ & $\begin{array}{c}\text { World Average } 1960-2010 \\
\text { Mean } \\
\text { (Std. Dev.) } \\
\text { N }\end{array}$ \\
\hline Intensity & $\begin{array}{c}0.70 \\
(0.47) \\
N=27\end{array}$ & $\begin{array}{c}0.48 \\
(0.50) \\
N=151\end{array}$ & \\
\hline Population in thousands & $\begin{array}{l}7,262 \\
(5,144) \\
N=25\end{array}$ & $\begin{array}{l}101,407 \\
(221,390) \\
N=126\end{array}$ & $\begin{array}{c}22,849 \\
(91,611) \\
N=11,284\end{array}$ \\
\hline GDP per capita & $\begin{array}{l}1,850 \\
(2,519) \\
N=23\end{array}$ & $\begin{array}{c}3,668 \\
(5,101) \\
N=107\end{array}$ & $\begin{array}{c}8,578 \\
(11,097) \\
N=8,664\end{array}$ \\
\hline Trade Openness ( $\%$ of GDP) & $\begin{array}{l}47.34 \\
(32.97) \\
N=23\end{array}$ & $\begin{array}{c}50.23 \\
(37.88) \\
N=107\end{array}$ & $\begin{array}{c}69.20 \\
(46.89) \\
N=8,664\end{array}$ \\
\hline PolityIV & $\begin{array}{c}-3.73 \\
(4.21) \\
N=22\end{array}$ & $\begin{array}{c}-0.01 \\
(6.59) \\
N=146\end{array}$ & $\begin{array}{c}0.49 \\
(7.49) \\
N=7,947\end{array}$ \\
\hline Distance from the UK in $1,000 \mathrm{~km}$ & $\begin{array}{c}4.37 \\
(2.25) \\
N=27\end{array}$ & $\begin{array}{c}5.55 \\
(2.74) \\
N=151\end{array}$ & $\begin{array}{c}5.46 \\
2.77 \\
N=6,676\end{array}$ \\
\hline Distance from France in $1,000 \mathrm{~km}$ & $\begin{array}{c}3.65 \\
(2.27) \\
N=27\end{array}$ & $\begin{array}{c}5.05 \\
(2.86) \\
N=151\end{array}$ & $\begin{array}{c}4.95 \\
(2.94) \\
N=6,676\end{array}$ \\
\hline Distance from China in $1,000 \mathrm{~km}$ & $\begin{array}{c}5.29 \\
(2.74) \\
N=27\end{array}$ & $\begin{array}{c}4.19 \\
(4.20) \\
N=151\end{array}$ & $\begin{array}{c}6.11 \\
(4.33) \\
N=6,676\end{array}$ \\
\hline Distance from Russia in $1,000 \mathrm{~km}$ & $\begin{array}{c}3.55 \\
(2.18) \\
N=27\end{array}$ & $\begin{array}{c}3.46 \\
(2.98) \\
N=151\end{array}$ & $\begin{array}{c}4.47 \\
(3.32) \\
N=6,676\end{array}$ \\
\hline Distance from the US in $1,000 \mathrm{~km}$ & $\begin{array}{c}8.02 \\
(2.37) \\
N=27\end{array}$ & $\begin{array}{c}8.02 \\
(3.16) \\
N=151\end{array}$ & $\begin{array}{c}7.15 \\
(3.36) \\
N=6,676\end{array}$ \\
\hline Africa & $\begin{array}{c}0.63 \\
(0.49) \\
N=27\end{array}$ & $\begin{array}{c}0.32 \\
(0.47) \\
N=151\end{array}$ & $\begin{array}{c}0.29 \\
(0.45) \\
N=11,727\end{array}$ \\
\hline Asia & $\begin{array}{c}0.11 \\
(0.32) \\
N=27\end{array}$ & $\begin{array}{c}0.46 \\
(0.50) \\
N=151\end{array}$ & $\begin{array}{c}0.24 \\
(0.42) \\
N=11,727\end{array}$ \\
\hline Europe & $\begin{array}{c}0.22 \\
(0.42) \\
N=27\end{array}$ & $\begin{array}{c}0.09 \\
(0.28) \\
N=151\end{array}$ & $\begin{array}{c}0.23 \\
(0.42) \\
N=11,727\end{array}$ \\
\hline North America & $\begin{array}{c}0.04 \\
(0.19) \\
N=27\end{array}$ & $\begin{array}{c}0.04 \\
(0.20) \\
N=151\end{array}$ & $\begin{array}{c}0.10 \\
(0.30) \\
N=11,727\end{array}$ \\
\hline Oceania & $\begin{array}{c}0 \\
(0.00) \\
N=27\end{array}$ & $\begin{array}{c}0.01 \\
(0.08) \\
N=151\end{array}$ & $\begin{array}{c}0.05 \\
(0.22) \\
N=11,727\end{array}$ \\
\hline Latin America & $\begin{array}{c}0 \\
(0.00) \\
N=27\end{array}$ & $\begin{array}{c}0.09 \\
(0.28) \\
N=151\end{array}$ & $\begin{array}{c}0.10 \\
(0.30) \\
N=11,727\end{array}$ \\
\hline
\end{tabular}


Table 4: Basic results and differences across continents. Displaying odds ratios

\begin{tabular}{|c|c|c|c|c|c|c|}
\hline & $\begin{array}{c}(1) \\
\text { interv }\end{array}$ & $\begin{array}{c}(2) \\
\text { interv }\end{array}$ & $\begin{array}{c}(3) \\
\text { interv }\end{array}$ & $\begin{array}{c}(4) \\
\text { interv }\end{array}$ & $\begin{array}{c}(5) \\
\text { interv }\end{array}$ & $\begin{array}{c}(6) \\
\text { interv }\end{array}$ \\
\hline africa & $\begin{array}{c}7.083^{*} \\
(7.529)\end{array}$ & $\begin{array}{l}8.799^{* *} \\
(9.493)\end{array}$ & $\begin{array}{c}6.076 \\
(6.723)\end{array}$ & $\begin{array}{c}0.965 \\
(1.324)\end{array}$ & $\begin{array}{c}0.609 \\
(0.874)\end{array}$ & $\begin{array}{c}0.709 \\
(1.056)\end{array}$ \\
\hline asia & $\begin{array}{c}0.857 \\
(1.013)\end{array}$ & $\begin{array}{c}0.793 \\
(0.945)\end{array}$ & $\begin{array}{c}1.391 \\
(1.722)\end{array}$ & $\begin{array}{c}0.698 \\
(1.083)\end{array}$ & $\begin{array}{c}0.701 \\
(1.104)\end{array}$ & $\begin{array}{c}0.487 \\
(0.821)\end{array}$ \\
\hline europe & $\begin{array}{c}9.231^{*} \\
(10.50)\end{array}$ & $\begin{array}{l}11.05^{* *} \\
(12.82)\end{array}$ & $\begin{array}{l}10.87^{* *} \\
(13.01)\end{array}$ & $\begin{array}{c}49.36^{* * *} \\
(67.24)\end{array}$ & $\begin{array}{l}24.93^{* *} \\
(37.87)\end{array}$ & $\begin{array}{l}16.10^{*} \\
(25.95)\end{array}$ \\
\hline intensity & & $\begin{array}{c}3.951^{* * *} \\
(1.927)\end{array}$ & $\begin{array}{c}6.026^{* * *} \\
(3.398)\end{array}$ & $\begin{array}{l}5.141^{* *} \\
(3.408)\end{array}$ & $\begin{array}{c}2.655 \\
(1.938)\end{array}$ & $\begin{array}{l}7.388^{* *} \\
(7.013)\end{array}$ \\
\hline $\operatorname{lnpop}$ & & & $\begin{array}{c}0.557^{* * *} \\
(0.117)\end{array}$ & $\begin{array}{c}0.351^{* * *} \\
(0.110)\end{array}$ & $\begin{array}{c}0.335^{* * *} \\
(0.117)\end{array}$ & $\begin{array}{c}0.289^{* * *} \\
(0.125)\end{array}$ \\
\hline $\operatorname{lngdp}$ & & & & $\begin{array}{l}0.280^{* *} \\
(0.144)\end{array}$ & $\begin{array}{l}0.258^{* *} \\
(0.153)\end{array}$ & $\begin{array}{c}0.366^{*} \\
(0.217)\end{array}$ \\
\hline lnopen & & & & $\begin{array}{l}0.356^{* *} \\
(0.173)\end{array}$ & $\begin{array}{l}0.345^{* *} \\
(0.172)\end{array}$ & $\begin{array}{c}0.0981^{* *} \\
(0.0954)\end{array}$ \\
\hline polityIV & & & & & $\begin{array}{c}0.948 \\
(0.0623)\end{array}$ & $\begin{array}{c}0.893 \\
(0.0696)\end{array}$ \\
\hline landlocked & & & & & $\begin{array}{c}0.627 \\
(0.477)\end{array}$ & $\begin{array}{c}0.673 \\
(0.508)\end{array}$ \\
\hline island & & & & & $\begin{array}{c}0.267 \\
(0.378)\end{array}$ & $\begin{array}{c}0.102 \\
(0.181)\end{array}$ \\
\hline year & & & & & & $\begin{array}{c}1.112^{* *} \\
(0.0567)\end{array}$ \\
\hline$N$ & 178 & 178 & 151 & 130 & 125 & 125 \\
\hline
\end{tabular}

Exponentiated coefficients; Standard errors in parentheses

${ }^{*} p<0.10,{ }^{* *} p<0.05,{ }^{* * *} p<0.01$ 
Table 5: Basic results, including the geographical distance from the United Kingdom. Displaying odds ratios

\begin{tabular}{|c|c|c|c|c|c|c|}
\hline & $\begin{array}{c}(1) \\
\text { interv }\end{array}$ & $\begin{array}{c}(2) \\
\text { interv }\end{array}$ & $\begin{array}{c}(3) \\
\text { interv }\end{array}$ & $\begin{array}{c}(4) \\
\text { interv }\end{array}$ & $\begin{array}{c}(5) \\
\text { interv }\end{array}$ & $\begin{array}{c}(6) \\
\text { interv }\end{array}$ \\
\hline ukdist & $\begin{array}{c}0.839^{* *} \\
(0.0714)\end{array}$ & $\begin{array}{c}0.821^{* *} \\
(0.0705)\end{array}$ & $\begin{array}{c}0.833^{*} \\
(0.0824)\end{array}$ & $\begin{array}{c}0.638^{* * *} \\
(0.101)\end{array}$ & $\begin{array}{l}0.671^{* *} \\
(0.121)\end{array}$ & $\begin{array}{c}0.691^{*} \\
(0.140)\end{array}$ \\
\hline intensity & & $\begin{array}{l}2.959^{* *} \\
(1.366)\end{array}$ & $\begin{array}{c}5.218^{* * *} \\
(2.835)\end{array}$ & $\begin{array}{l}4.696^{* *} \\
(2.871)\end{array}$ & $\begin{array}{l}2.937^{*} \\
(1.907)\end{array}$ & $\begin{array}{l}6.641^{* *} \\
(5.314)\end{array}$ \\
\hline $\operatorname{lnpop}$ & & & $\begin{array}{c}0.527^{* * *} \\
(0.100)\end{array}$ & $\begin{array}{l}0.342^{* * *} \\
(0.0996)\end{array}$ & $\begin{array}{c}0.357^{* * *} \\
(0.109)\end{array}$ & $\begin{array}{c}0.276^{* * *} \\
(0.112)\end{array}$ \\
\hline $\operatorname{lngdp}$ & & & & $\begin{array}{l}0.446^{* *} \\
(0.142)\end{array}$ & $\begin{array}{l}0.403^{* *} \\
(0.179)\end{array}$ & $\begin{array}{c}0.481 \\
(0.216)\end{array}$ \\
\hline lnopen & & & & $\begin{array}{c}0.329^{* *} \\
(0.159)\end{array}$ & $\begin{array}{l}0.325^{* *} \\
(0.160)\end{array}$ & $\begin{array}{c}0.0952^{* * *} \\
(0.0842)\end{array}$ \\
\hline polityIV & & & & & $\begin{array}{c}0.973 \\
(0.0566)\end{array}$ & $\begin{array}{c}0.906 \\
(0.0641)\end{array}$ \\
\hline landlocked & & & & & $\begin{array}{c}0.742 \\
(0.562)\end{array}$ & $\begin{array}{c}0.746 \\
(0.566)\end{array}$ \\
\hline island & & & & & $\begin{array}{c}0.754 \\
(1.087)\end{array}$ & $\begin{array}{c}0.235 \\
(0.426)\end{array}$ \\
\hline year & & & & & & $\begin{array}{c}1.104^{* *} \\
(0.0484)\end{array}$ \\
\hline$N$ & 178 & 178 & 151 & 130 & 125 & 125 \\
\hline
\end{tabular}

Exponentiated coefficients; Standard errors in parentheses

${ }^{*} p<0.10,{ }^{* *} p<0.05,{ }^{* * *} p<0.01$ 
Table 6: Basic results, including the geographical distance from France. Displaying odds ratios

\begin{tabular}{|c|c|c|c|c|c|c|}
\hline & $\begin{array}{c}(1) \\
\text { interv }\end{array}$ & $\begin{array}{c}(2) \\
\text { interv }\end{array}$ & $\begin{array}{c}(3) \\
\text { interv }\end{array}$ & $\begin{array}{c}(4) \\
\text { interv }\end{array}$ & $\begin{array}{c}(5) \\
\text { interv }\end{array}$ & $\begin{array}{c}(6) \\
\text { interv }\end{array}$ \\
\hline fradist & $\begin{array}{c}0.819^{* *} \\
(0.0701)\end{array}$ & $\begin{array}{l}0.799^{* * *} \\
(0.0693)\end{array}$ & $\begin{array}{c}0.822^{* *} \\
(0.0808)\end{array}$ & $\begin{array}{c}0.655^{* * *} \\
(0.100)\end{array}$ & $\begin{array}{c}0.692^{* *} \\
(0.121)\end{array}$ & $\begin{array}{c}0.711^{*} \\
(0.139)\end{array}$ \\
\hline intensity & & $\begin{array}{l}3.058^{* *} \\
(1.420)\end{array}$ & $\begin{array}{c}5.275^{* * *} \\
(2.869)\end{array}$ & $\begin{array}{l}4.735^{* *} \\
(2.883)\end{array}$ & $\begin{array}{c}2.993^{*} \\
(1.937)\end{array}$ & $\begin{array}{l}6.722^{* *} \\
(5.335)\end{array}$ \\
\hline $\operatorname{lnpop}$ & & & $\begin{array}{c}0.527^{* * *} \\
(0.101)\end{array}$ & $\begin{array}{c}0.352^{* * *} \\
(0.100)\end{array}$ & $\begin{array}{c}0.367^{* * *} \\
(0.110)\end{array}$ & $\begin{array}{c}0.280^{* * *} \\
(0.113)\end{array}$ \\
\hline $\operatorname{lngdp}$ & & & & $\begin{array}{c}0.487^{* *} \\
(0.150)\end{array}$ & $\begin{array}{c}0.433^{*} \\
(0.188)\end{array}$ & $\begin{array}{c}0.517 \\
(0.226)\end{array}$ \\
\hline lnopen & & & & $\begin{array}{c}0.332^{* *} \\
(0.159)\end{array}$ & $\begin{array}{l}0.332^{* *} \\
(0.161)\end{array}$ & $\begin{array}{c}0.0936^{* * *} \\
(0.0833)\end{array}$ \\
\hline polityIV & & & & & $\begin{array}{c}0.975 \\
(0.0563)\end{array}$ & $\begin{array}{c}0.904 \\
(0.0644)\end{array}$ \\
\hline landlocked & & & & & $\begin{array}{c}0.742 \\
(0.560)\end{array}$ & $\begin{array}{c}0.748 \\
(0.565)\end{array}$ \\
\hline island & & & & & $\begin{array}{c}0.734 \\
(1.081)\end{array}$ & $\begin{array}{c}0.218 \\
(0.401)\end{array}$ \\
\hline year & & & & & & $\begin{array}{c}1.107^{* *} \\
(0.0488)\end{array}$ \\
\hline$N$ & 178 & 178 & 151 & 130 & 125 & 125 \\
\hline
\end{tabular}

Exponentiated coefficients; Standard errors in parentheses

${ }^{*} p<0.10,{ }^{* *} p<0.05,{ }^{* * *} p<0.01$ 
Table 7: Basic results, including the geographical distance from China, Russia, and the US (distances in $1,000 \mathrm{~km}$ ). Displaying odds ratios

\begin{tabular}{|c|c|c|c|c|c|c|}
\hline & $\begin{array}{c}(1) \\
\text { interv }\end{array}$ & $\begin{array}{c}(2) \\
\text { interv }\end{array}$ & $\begin{array}{c}(3) \\
\text { interv }\end{array}$ & $\begin{array}{c}(4) \\
\text { interv }\end{array}$ & $\begin{array}{c}(5) \\
\text { interv }\end{array}$ & $\begin{array}{c}(6) \\
\text { interv }\end{array}$ \\
\hline intensity & $\begin{array}{l}2.705^{* *} \\
(1.232)\end{array}$ & $\begin{array}{l}5.569^{* *} \\
(4.257)\end{array}$ & $\begin{array}{c}2.605^{* *} \\
(1.177)\end{array}$ & $\begin{array}{l}5.250^{* *} \\
(3.970)\end{array}$ & $\begin{array}{l}2.611^{* *} \\
(1.181)\end{array}$ & $\begin{array}{l}5.920^{* *} \\
(4.586)\end{array}$ \\
\hline chidist & $\begin{array}{c}1.073 \\
(0.0532)\end{array}$ & $\begin{array}{c}0.988 \\
(0.113)\end{array}$ & & & & \\
\hline rusdist & & & $\begin{array}{c}1.011 \\
(0.0735)\end{array}$ & $\begin{array}{c}0.859 \\
(0.140)\end{array}$ & & \\
\hline usdist & & & & & $\begin{array}{c}0.993 \\
(0.0680)\end{array}$ & $\begin{array}{c}0.882 \\
(0.113)\end{array}$ \\
\hline $\operatorname{lnpop}$ & & $\begin{array}{c}0.303^{* * *} \\
(0.114)\end{array}$ & & $\begin{array}{c}0.279^{* * *} \\
(0.107)\end{array}$ & & $\begin{array}{c}0.309^{* * *} \\
(0.115)\end{array}$ \\
\hline $\operatorname{lngdp}$ & & $\begin{array}{c}0.571 \\
(0.244)\end{array}$ & & $\begin{array}{c}0.552 \\
(0.234)\end{array}$ & & $\begin{array}{c}0.463 \\
(0.229)\end{array}$ \\
\hline lnopen & & $\begin{array}{l}0.122^{* * *} \\
(0.0981)\end{array}$ & & $\begin{array}{l}0.121^{* * *} \\
(0.0962)\end{array}$ & & $\begin{array}{l}0.123^{* *} \\
(0.101)\end{array}$ \\
\hline polityIV & & $\begin{array}{c}0.911 \\
(0.0618)\end{array}$ & & $\begin{array}{c}0.911 \\
(0.0624)\end{array}$ & & $\begin{array}{c}0.912 \\
(0.0618)\end{array}$ \\
\hline landlocked & & $\begin{array}{c}0.759 \\
(0.571)\end{array}$ & & $\begin{array}{c}0.664 \\
(0.499)\end{array}$ & & $\begin{array}{c}0.830 \\
(0.622)\end{array}$ \\
\hline island & & $\begin{array}{l}0.0757 \\
(0.129)\end{array}$ & & $\begin{array}{l}0.0886 \\
(0.154)\end{array}$ & & $\begin{array}{c}0.106 \\
(0.174)\end{array}$ \\
\hline year & & $\begin{array}{c}1.110^{* *} \\
(0.0469)\end{array}$ & & $\begin{array}{c}1.104^{* *} \\
(0.0459)\end{array}$ & & $\begin{array}{c}1.109^{* *} \\
(0.0468)\end{array}$ \\
\hline$N$ & 178 & 125 & 178 & 125 & 178 & 125 \\
\hline
\end{tabular}

Exponentiated coefficients; Standard errors in parentheses

${ }^{*} p<0.10,{ }^{* *} p<0.05,{ }^{* * *} p<0.01$ 